\section{A microbiologist's vade-mecum}

\section{John Postgate}

The Prokaryotes: A Handbook on Habitats, Isolation, and Identification of Bacteria. Edited by Mortimer P. Starr et al. Two parts, pp.2,596, ISBN 3-540-08871-7 (Springer-Verlag: 1982.) DM 880, \$410.

To Do this magnificent work justice would require a team of reviewers almost as numerous as its 182 contributors. For it is nothing less than a comprehensive handbook of bacteriology: a detailed and up-to-date guide to the isolation, cultivation and identification of almost all the known bacteria.

The two volumes are divided into 23 sections (A-W inclusive), each of which comprises between 2 and 18 chapters Section A consists of 6 introductory essays, the first of which is an excellent account of prokaryotic diversity which contrives to be highly informative as well as entertaining - see Table 13, for example. The other essays cover habitats, including diseased man and animals, as well as plants; principles of isolation, cultivation and conservation; and principles of characterization and identification. I found each of them thorough and informative; they provide an excellent hors d'oeuvre to the subsequent 22 courses.

I shall not have space to review those in any depth, so I shall indicate the pattern of the books by describing Section B, which deals with the phototrophic bacteria. It consists of 12 chapters. After a general introduction presenting their physiology and anatomy, come highly practical chapters on the isolation of cyanobacteria from normal and saline environments. A contribution on the habitats, isolation and characterization of vacuolate cyanobacteria is followed by one of broadly similar pattern on thermophilic cyanobacteria. Next is a more taxonomic contribution on the genera of cyanobacteria. The prochlorophytes are then briefly dealt with, preceding a short account of the isolation and cultivation of rhodospirilla. The genus Ectothiorhodospira gets its own chapter, followed by the chromatia and chlorobia; these two chapters collectively cover the phototrophic sulphur bacteria. The isolation of the photosynthetic flexibacteria is discussed next, and the section is concluded by a key to the classification of the non-oxygenic phototrophs. As this description indicates, the phototrophic bacteria are dealt with very thoroughly and the emphasis is generally highly practical: on media, culture, enrichment, storage and so on.

This pattern, a general essay introducing the detailed articles, is more or less followed in each section throughout the book. Section $\mathrm{C}$ is on the gliding bacteria, and $\mathrm{D}-$ the shortest, containing two chapters - deals with some sheathed and vacuolate bacteria. Section $\mathbf{E}$ covers budding and appendaged bacteria; $\mathrm{F}$, the spirochaetes; $G$, some helical and curved bacteria; $\mathrm{H}$, the pseudomonads; I, the diazotrophs with Agrobacterium and Alcaligenes thrown in. Section $\mathrm{J}$ is a ragbag of mixed chemotrophs (sulphate reducers, methylotrophs, methanogens, halobacteria and so on), the least logical but nevertheless a most useful section. Section $\mathrm{K}$ covers obligate chemotrophs, bringing us to the end of what might broadly be called "environmental" bacteria.

It is a pity that Section $\mathrm{L}$, the last in Vol.1, covering medically important Gram-negative rods (Brucella, Legionella and so on), was not transferred to the second volume but I suppose binding problems would have arisen. Volume 2 itself covers inter alia most of the medically important bacteria, as well as rumen and spoilage organisms. Section $\mathbf{M}$ is on enterobacteria and vibrios; N, various facultative rods; $\mathrm{O}$, anaerobic rods; $\mathrm{P}$ and $\mathrm{Q}$, cocci; $\mathrm{R}$ and $\mathrm{S}$, spore formers. Section $T$, on coryneforms, leads logically to Section $U$ on actinomycetes. Finally, Section V deals with the obligate symbionts and $\mathrm{W}$ with the wall-deficient bacteria.

I found it impracticable to go through all 169 chapters in detail but I have read carefully about 20 that I know something about

\section{Ubiquitous gels}

\section{E.G. Richards}

Electrophoresis: Theory, Techniques, and Biochemical and Clinical Applications. By Anthony T. Andrews. Pp.336. ISBN 0-19-854626-2. (Clarendon/Oxford University Press: 1982.) £25, \$59.

DR Andrews remarks in his preface to this volume that well over half of all research papers in biochemistry involve electrophoresis. This impressive statistic calls for comment. Books with similar titles published 30 years ago would be mainly about free boundary electrophoresis à la Tiselius, a technique requiring complicated and expensive equipment; in contrast the present book is predominantly about zonal electrophoresis in polyacrylamide gels. For this the equipment is simple and cheap; the method is easy to master and no great sophistication is required to interpret the results. Anybody can do it, and, as the literature suggests, does.

Gels, polyacrylamide, starch or agarose provide the most favoured media for zonal electrophoresis with polyacrylamide well ahead of the field. It is 23 years since Raymond and Weintraub introduced the latter and thus strange that there is still no and have dipped into most of the rest. As with the introductory essays, I am impressed by the quality and conciseness of the writing and the high information content. The authors are leading experts in their particular fields and their names, too many to list, will be familiar to all microbiologists. Some of the arrangement is idiosyncratic, however, and some of the classifications are inconsistent with the eighth edition of Bergey's Manual (Williams \& Wilkins, 1974), usually for good reasons. No handbook of this kind can be perfect: I combed Section $\mathrm{C}$ (gliding bacteria) for a cross-reference to Desulfonema, which rightly appears among sulphate-reducing bacteria, although it glides. It is also a pity that all the colour pictures are clustered at the front of Vol.1.

A major concern to most potential customers will be the overlap with Bergey's Manual. Certainly, The Prokaryotes covers much of the information available in the eighth edition of Bergey but it is a far more ambitious and up-to-date work: it is not simply a determinative system, but a real laboratory handbook for microbiologists. I recommend it strongly to any microbiological library; it is an invaluable guide and reference work which ought to be readily available to every working microbiologist.

John Postgate is Professor of Microbiology at the University of Sussex and Director of the Agricultural Research Council's Unit of Nitrogen Fixation.

clear picture of the structure of such gels or how they exert their sieving effect in the electrophoretic process. Such understanding as we have is empirical. A consequence is that the technique still resembles more an art than a science. Recipes, with which the book abounds, are handed down from generation to generation of research students, and anomalies and artifacts, many of which Dr Andrews discusses, are there to dishearten the novice and mystify the expert.

Such theory that there is is adequately displayed, albeit occasionally a little shakily, and it is a minor criticism that it is developed in parallel for proteins and for nucleic acids. This leads to both repetition and a failure to indicate how lessons learnt from one class of macromolecules are relevant to the other.

Thus the major thrust is practical. Dr Andrews is to be congratulated on providing under one cover, succinct, clear and practical descriptions of electrophoresis in polyacrylamide and other media in most of the usual variations, as well as of related techniques including isoelectric-focusing, isotachophoresis, immuno-electrophoresis and affinity electrophoresis.

E.G. Richards is Senior Lecturer at the Department of Biophysics at King's College, University of London. 